\title{
INNOVATIVE APPROACH IN THE ESTIMATOLOGY OF FINANCIAL INSTITUTIONS ECONOMIC SECURITY: POSSIBILITIES OF USE IN MANAGEMENT AND REGULATORY ACTIVITY WITHIN THE MEANS OF PROVISION OF THE STATE FINANCIAL SECURITY
}

\author{
Nataliia Zachosova ${ }^{1}$
}

\begin{abstract}
Ukraine's integration into the European economic space requires the conformity of many segments of the domestic economic system to the standards, norms and traditions of the EU. The financial market and its participants form the financial basis for economic development, mediate the capital movement, make it possible to form a powerful investment resource and provide financial cooperation at the supranational level. However, domestic financial services markets are now destabilized; the volumes of assets used by their professional participants are significantly lower than the financial potential of the financial institutions of the European Union markets, to the convergence with which the Ukrainian financial sector terribly seeks. In addition to the capacity dimension, a large number of destabilizing factors that have been contributing to its development in recent years remain a problematic aspect of the domestic financial market evolution. The purpose of this study is to develop an innovative approach to assessing the level of financial institutions' economic security, as well as substantiate its use in a management activity of company management to ensure a high level of profitability and in the regulatory activity of state authorities in order to guarantee the financial security of the state. Methodology. The methods of research will be: methods of induction and deduction, scientific abstraction and generalization, a method of organizing, expert method, graphical method for the identification of intermediate and final results of the study, as well as a generalization method for formulating conclusions and proposals at the end of the conducted scientific research. Results of the survey. The author's methodical approach to assessing the level of financial institutions economic security is offered. The possibility of using the results of assessing the level of financial institutions economic security by the top management of professional participants in the financial market has been established. The directions of its application by the national regulators of the financial market for the purpose of ensuring the financial security of the state through the mechanism of monitoring and control of the results of activities of financial intermediaries are determined. Practical implications. The proposed innovative approach in the estimatology of financial institutions economic security should be used by the state regulators of the financial market, in particular, by the National Bank of Ukraine and the National Commission, which performs state regulation in the field of financial services markets, to monitor the activities of professional financial market participants in order to conduct advisory and consultative work with their owners and managers, as well as for the development of strategic guidelines for the provision of the state financial security. Value/originality. Methodological approaches to assessing the economic security level of financial institutions in the process of managing their activities should be the basis of documentary support for security management of the system of economic security, and their reuse after the introduction or modernization of the mechanism of economic security system management of financial institutions will allow diagnosing the level of its effectiveness and, if necessary, to change the target guidelines for managing the economic security system to ensure maximum levels of the protection for the economic interests of companies and their clients from threats, as well as to ensure a high level of financial security of the state.
\end{abstract}

Key words: economic security, financial institution, financial security, management, level of economic security, management decisions, regulation, evaluation.

JEL Classification: E44, G10, G18, 016

Corresponding author:

${ }^{1}$ Cherkasy National University named after Bogdan Khmelnytsky, Ukraine.

E-mail: natazachosova@gmail.com 


\section{Introduction}

The urgency of the research. Financial security occupies an important place in the system of economic security of any state, and the financial system and financial markets are the sources of a large number of threats to the normal functioning of both financial institutions and manufacturing and trading enterprises, whose costeffective activity, in turn, is the basis for normal state of financial security of all countries without exception. Thus, a stable, continuous, and productive activity of professional financial intermediaries is a prerequisite for improving the financial and, hence, economic situation at the macro level in the future. Consequently, the methodical task of assessing the economic security level, which was attained by the implementers of financial products and services, becomes relevant, since maintaining the normal functional state of the largest participants in the financial market becomes subject of national importance according to manifestations of economic imbalances and the effects of a political crisis.

Target setting. In the methodological plane, tools for assessing the economic security level of the certain types of financial institutions such as banks and insurance companies have been developed. However, at the application level, its use has not become widespread. For a number of financial intermediaries, for example, credit unions, investment and leasing companies, pawnshops, etc., there are no methodological tools for assessing the level of economic security. Thus, there is a need to identify the shortcomings of the existing methodological tools for diagnosing the financial institutions' economic security level and to make proposals for the development of a comprehensive methodology for diagnosing the economic security state, suitable for use by different types of professional participants in the financial market.

Actual scientific researches and issues analysis. Awareness of the problem of the need to ensure economic security at the macro level has a significant impact on the development of economic policies, both individual states and around the world, given the steady trend towards economic convergence and the economic system globalization. The fundamentals of security-oriented economic development were laid in the "new course" of the evolution of the US economy (Roosevelt, n.d.). The issue of economic security continues to be relevant, and in its context, awareness of the role of the financial market and its financial stability is emerging to solve the problem of securing the country's economic system from various financial threats, as evidenced by the work of the Nobel Prize winner 2001 (Stiglitz, 2002). R. Creamer notes that "the domination of the financial sector has become a mortal danger to our economic security" (Creamer, 2011). The state of macro markets was attributed to a level of financial security (Athanasoulis, Schiller, van Wincoop, 1999).

In the modern conditions of national and supranational economic systems and their financial segments development, the problem of security was disseminated in the scientific discussions of scholars of the whole world (Osberg, Sharpe, 2008; Ioan-Franc, Diamescu, 2010; Schimmel, Liu, Nicholls, Nechval, Yi-Lin Forrest, 2017). In the quest to provide recommendations for improving the level of economic security of the country, to the problems of the financial market and its professional participants functioning apply a lot of eminent scientists (Kopp, Kaffenberger, Wilson, 2017; Elliott, 2017; Matanda, 2015, Piotrovska, 2017). A comprehensive study of the issues of economic and financial security has revealed weaknesses in the mechanisms for diagnosing its current state. Some aspects of financial and economic security state analysis are studied in the publications of Polish scientists (Kosny, Piotrovska, n.d.) and researchers from Moldova (Perciun, Stratan, Timush, 2014). Americans suggest using the Economic Security Index as a new measure for research and policy analysis (Hacker, Huber, Nichols, Rehm, Schlesinger, Valletta, Craig, 2012). Ukraine also faces difficulties in establishing an assessment of the state of the national, economic, financial, and other components of the country security (Dyakonova, Nikitina, Sukhonos, Zhuravka, 2018; Momot, Ovchelupova, Solovyova, 2015; Shtefan, 2017; Kozachenko, 2016).

Uninvestigated parts of general matters defining. Without prejudice to the role of scientific developments aimed at studying the theory and practice of assessing the level of economic security of certain types of financial institutions, in particular, banks and insurance companies, further research and development of methodological approaches to the diagnosis of the state of economic security of professional participants in the financial market are necessary, given the importance of their effective activities to ensure the financial security of the state.

The analysis of the results of researches of foreign and domestic scientists made it possible to conclude that the existing methodological approaches to assessing the level of economic security of the state as a whole, as well as of certain types of economic entities, are currently obsolete. They do not take into account a number of important micro and macroeconomic indicators of economic development, and some of the indicators that continue to be calculated are excessively difficult to calculate, while others have lost their relevance. During the calculations, analysts find it difficult to find an information resource of the proper quality; most indicators are based on statistic data that is released too late for the timely identification of threats to individual components of economic security and their avoidance. However, the most significant disadvantage of traditional approaches to assessing the level of economic security of the state is the lack of indicator among the groups of indicators that would reflect the state of economic security of economic entities - the main producers, sellers and consumers of the national product, the resource base of the modern market economy, to which 
financial market professional members also belong. As an efficiently organized financial sector is the basis for the formation of a modern architecture of a viable economic system, and the qualitative evolution of the financial market is the basis for the development of the country's economy, within this study, it is worthwhile to focus on the issue of assessing the level of economic security of financial institutions as the main actors to ensure the functioning of financial services markets.

The research objective is to develop an innovative approach to assessing the level of financial institutions economic security, as well as substantiate its use in a management activity of company management to ensure a high level of profitability and in the regulatory activity of state authorities in order to guarantee the financial security of the state.

Methodology. The author's approach to the methodology for assessing the level of economic security of financial institutions is proposed. This approach involves an analysis of the values of quantitative indicators and characteristics of qualitative signs of the state of the functional components of the system of economic security, the assignment of ball assessments, finding the sum of points weighted by weight factors, and calculating on this basis the values of indices of the state of each functional component of economic security system. The sum of these values allows us to determine which level of economic security - critical, minimum, satisfactory, high or maximum - has provided the financial institution with the process of managing the system of own economic security.

The logic of material presentation. At the first stage of scientific work, the author offered the representation of the approach to the staged development of a methodology for assessing the financial institutions' economic security level. At the next stage of the study, the author proposed indicators for assessing the level of economic security of financial institutions. The methodological approach to assessing the level of economic security of financial institutions was described. The study ends with the list of possibilities of using the results of assessing economic security level in management and regulatory activity.

\section{Representation of the approach to the staged development of a methodology for assessing the financial institutions' economic security level}

The author's approach to assessing the level of financial institutions' economic security is based on several assumptions. Firstly, the diagnosis of the economic security of financial market professional participants should be conducted using the expert method. Experts should be the representatives of financial intermediaries' top management. Such a choice of the method of evaluation was made due to the specificity of the economic security state indicators, which should be taken into account and which cannot be mathematically calculated. Secondly, a list of indices for obtaining a reliable estimate of the economic security level should be formed using the principle of consistency - to take into account the characteristics of the state of various functional components of the economic security system. However, the proposed indicators should be easy to calculate or determine, since the assessment of economic security should be not only accurate but also timely. Thirdly, in order to ensure universality and understanding of the significance of each calculated indicator, positive or negative for the state of economic security, a final evaluation of their values is proposed based on the scorecard model. Three variants of the possible score are presented - 1, 2 and 3 points. Fourth, in order for the results of the analytical work to be used as an informative basis for making managerial decisions, it is advisable to transform quantitative assessment of economic security level into a qualitative characteristic of its state. Fifth, it is necessary to take into account the specific characteristics of each type of financial institution in the process of analytical work. Given this, using a universal approach to assessing the level of economic security of financial institutions, the mechanism for its diagnosis should include the possibility of taking into account the particularities of a specific type of financial intermediary, which serves as an object of analysis.

A schematic picture of the approach to staged development of a methodology for assessing the level of economic security of financial institutions is shown in Figure 1.

Consequently, the development of a methodology for assessing the level of economic security of financial institution was carried out in several stages. Atthefirststage, a list of intermediate indices for evaluation was defined, the significance of which allowed to characterize the state of functional components of the universal comprehensive system of economic security of a professional participant in the financial market. At the second stage, a list of specific indicators was formed, on which the estimation of each intermediate indice was formed. These indicators reflect the effects of the institution's activities on the state of one or another component of the economic security system. At the third stage, the methods, ways, and procedures for calculating the proposed indicators were determined and their normative, threshold, and oriented values were established.

At the fourth stage, information sources were searched for the information and data needed to calculate the indicators within each intermediate indice. Given the periodicity of updating information on the status of financial institutions in generally available resource bases, it is proposed to conduct an assessment of the economic security level once a year. In the internal management structure of the financial institution, carrying out the diagnostics of the level of economic 


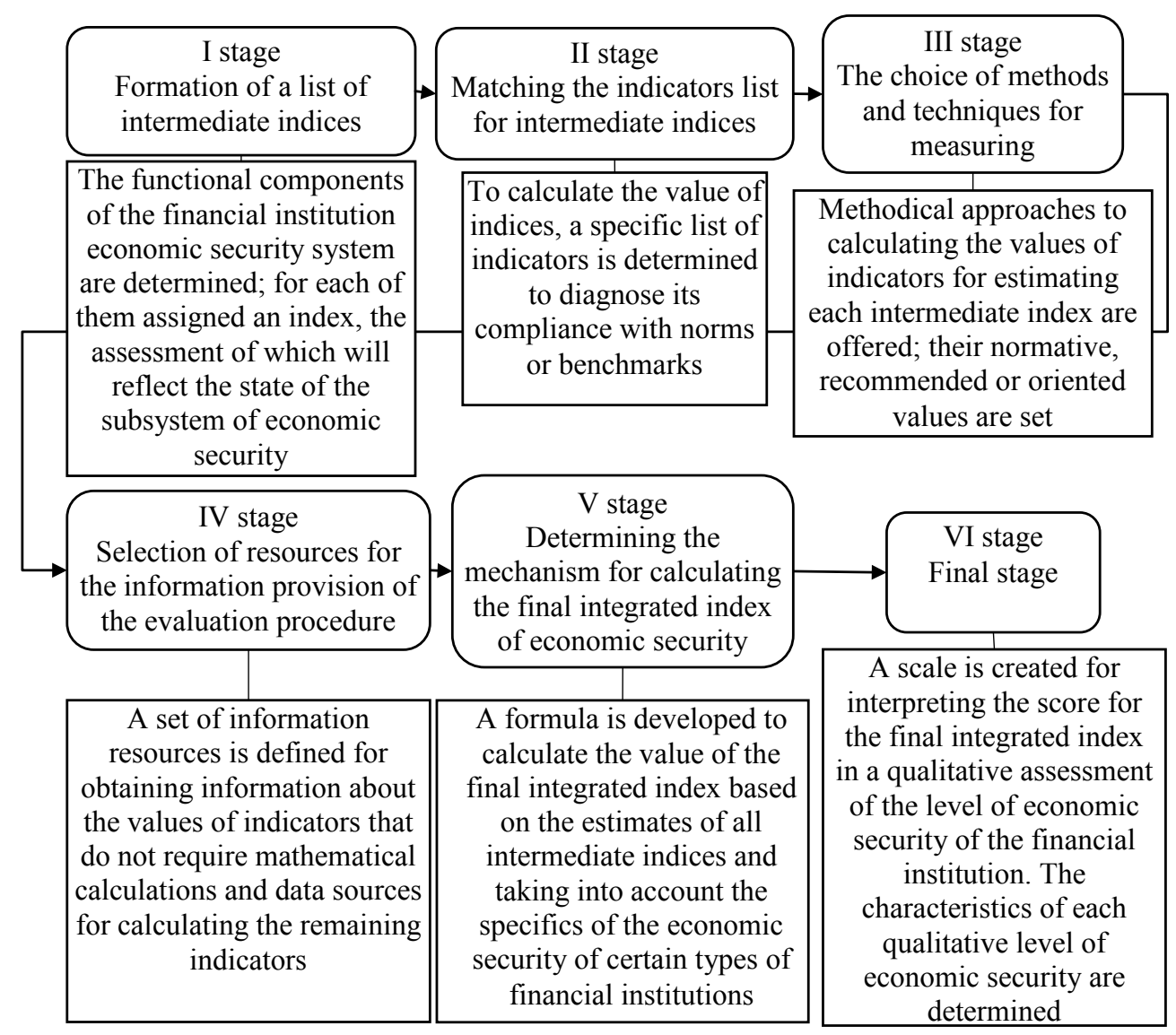

Figure 1. Schematic representation of the approach to the staged development of a methodology for assessing the financial institutions economic security level

Source: made by the authors

security, it is advisable to entrust the specialists of the economic security service, and in case of its absence, an outsider person or organization may be involved in the outsourcing process for the professional performance of this task. At the fifth stage, a final integrated indice of the economic security level was developed, which was determined taking into account the specific weight of each indice of the state of the functional components of the economic security system of financial institutions. It was at this stage that it was possible to ensure that the specifics of the functioning of each type of financial institution were taken into account in the process of assessing the level of their economic security. At the sixth stage, a mechanism for transforming the value of the integral indice into a qualitative characteristic of the state of economic security of a financial institution was proposed, and a scale for the qualitative assessment of the key importance of the financial security level of the financial intermediary was formed. In the long run, it can be recommended the form of the economic security level report, which will be one of the sources of information and analytical support for the process of financial institutions economic security system management for their top management needs. Also, such a report can be recognized at the level of state regulators of financial services markets as a mandatory form for providing information on the status of financial intermediaries. In this case, the assessment of the level of economic security will become an additional norm for the regulation of the activities of financial institutions, the observance of which will improve the level of financial security of the state.

\section{Indicators for assessing the level of economic security of financial institutions}

A set of indicators for assessing the financial institutions' economic security is contained in Table 1.

Thus, taking into account the sources of threats to the economic security of financial institutions, it is proposed to allocate eight of its functional subsystems, the state of which must be assessed in the diagnostic process: financial, intellectual and personnel, property (material), physical (power), information and analytical, technological, legal, market (external). Accordingly, the value of the final (integral) indice of the economic security level will be based on the estimates of the eight intermediate indices of the state of each of the subsystems of the economic security system of financial institutions. 
Vol. 5, No. 2, 2019

Table 1

Proposed indicators for assessing the level of economic security of financial institutions

\begin{tabular}{|c|c|c|c|c|}
\hline \multirow{2}{*}{$\begin{array}{l}\text { Intermediate } \\
\text { indexes }\end{array}$} & \multirow[b]{2}{*}{ Indicators for indexes } & \multicolumn{3}{|c|}{ Oriented (normative, threshold) values of indicators } \\
\hline & & $\begin{array}{l}\text { Low value } \\
\text { (1 point) }\end{array}$ & $\begin{array}{l}\text { Satisfactory value } \\
\text { (2 points) }\end{array}$ & $\begin{array}{l}\text { Optimal value } \\
\text { (3 points) }\end{array}$ \\
\hline 1 & 2 & 3 & 4 & 5 \\
\hline \multirow[t]{5}{*}{$\begin{array}{l}\text { 1. Financial security } \\
\text { index }\end{array}$} & The result of economic activity & Loss & Profitability & $\begin{array}{l}\text { Growth of profitability } \\
\text { in dynamics }\end{array}$ \\
\hline & Financial independence (coefficient) & Less than 0.5 & More than 0.5 & 1 \\
\hline & Liquidity level & Lower than normal & Corresponds to the norm & Higher than normal \\
\hline & $\begin{array}{l}\text { Compliance with economic norms } \\
\text { (prudential norms, regulatory } \\
\text { requirements) }\end{array}$ & Does not meet them & $\begin{array}{l}\text { Corresponds to } 90 \%, \\
\text { discrepancies are } \\
\text { eliminated }\end{array}$ & Fully responsible \\
\hline & $\begin{array}{l}\text { Estimation of financial services } \\
\text { consumers economic security level }\end{array}$ & No & $\begin{array}{l}\text { Conducted for individual } \\
\text { clients }\end{array}$ & $\begin{array}{l}\text { Conducted for all } \\
\text { clients }\end{array}$ \\
\hline \multirow{5}{*}{$\begin{array}{l}\text { 2. Intellectual and } \\
\text { personnel security } \\
\text { index }\end{array}$} & The higher education level of the staff & Up to $80 \%$ & $81-90 \%$ & More than $91 \%$ \\
\hline & $\begin{array}{l}\text { Personnel work experience in financial } \\
\text { institutions }\end{array}$ & Up to 2 years & $2-5$ years old & More than 5 years \\
\hline & The period of work in this institution & Up to 1 year & 1-2 years & More than 2 years \\
\hline & $\%$ of people with economic education & Up to $30 \%$ & $31-60 \%$ & More than $61 \%$ \\
\hline & $\%$ of temporarily employed persons & More than 20\% & $1-10 \%$ & $0 \%$ \\
\hline \multirow{5}{*}{$\begin{array}{l}\text { 3. Property } \\
\text { (material) security } \\
\text { index }\end{array}$} & $\begin{array}{l}\text { The volume of assets (in comparison } \\
\text { with average market value) }\end{array}$ & Less & At the level & More \\
\hline & Depreciation of fixed assets & More than $50 \%$ & $30-50 \%$ & Up to $30 \%$ \\
\hline & Branch network & Only 1 office & Up to 10 offices & 10 or more outlets \\
\hline & $\begin{array}{l}\text { Ownership of premises where offices } \\
\text { are located }\end{array}$ & Short Term Rentals & Long term lease & $\begin{array}{l}\text { Ownership of the } \\
\text { institution }\end{array}$ \\
\hline & Frequency of audit & $\begin{array}{l}\text { Less than once a year } \\
\text { or at the request of the } \\
\text { regulator }\end{array}$ & Once a year & $\begin{array}{l}\text { More than once a year } \\
\text { (at the initiative of the } \\
\text { management) }\end{array}$ \\
\hline \multirow{5}{*}{$\begin{array}{l}\text { 4. Physical (power) } \\
\text { security index }\end{array}$} & Presence of guards & No & Yes, 1 person & Yes, 2 or more people \\
\hline & Use of lattices, armoured areas & No & $\begin{array}{l}\text { In the premises where the } \\
\text { financial assets are kept }\end{array}$ & Yes, in all rooms \\
\hline & Services of professional security firms & Not used & Used as needed & $\begin{array}{l}\text { Service agreements are } \\
\text { concluded }\end{array}$ \\
\hline & Access control systems for resources & None & Separate elements & Full access control \\
\hline & Cases of signalling during the last year & $\begin{array}{l}3 \text { or more cases (or no } \\
\text { signalling or cases are } \\
\text { not fixed) }\end{array}$ & $\begin{array}{l}1-2 \text { times } \\
\text { (incl. accidentally) }\end{array}$ & $\begin{array}{l}\text { There was no case of } \\
\text { a crash }\end{array}$ \\
\hline \multirow{5}{*}{$\begin{array}{l}\text { 5. Information and } \\
\text { analytical security } \\
\text { index }\end{array}$} & $\begin{array}{l}\text { Analytical department in the } \\
\text { organizational structure }\end{array}$ & No & One person & Operates constantly \\
\hline & $\begin{array}{l}\text { Cases of information loss during the } \\
\text { last year }\end{array}$ & More than 2 cases & 1-2 minor cases & Not recorded \\
\hline & Access to the Internet (for personnel) & Full access & Limited access & $\begin{array}{l}\text { Access only to sites that } \\
\text { are required for work }\end{array}$ \\
\hline & Transparency level of activity & Up to $70 \%$ & $71-90 \%$ & $91-100 \%$ \\
\hline & $\begin{array}{l}\text { Sufficient information to make } \\
\text { managerial decisions }\end{array}$ & Information is missing & $\begin{array}{l}\text { Information is missing, } \\
\text { but it can be obtained }\end{array}$ & Full information \\
\hline \multirow{5}{*}{$\begin{array}{l}\text { 6. Technological } \\
\text { security index }\end{array}$} & $\%$ use of licensed software & Up to $80 \%$ & $80-90 \%$ & More than $90 \%$ \\
\hline & The frequency of software update & Not done & Monthly & Constantly \\
\hline & Depreciation of equipment & More than 51\% & $30-50 \%$ & Up to $30 \%$ \\
\hline & $\begin{array}{l}\text { IT department in the organizational } \\
\text { structure }\end{array}$ & No & One person & Operates constantly \\
\hline & $\begin{array}{l}\text { Speed recovery of equipment after } \\
\text { failures }\end{array}$ & More than a day & During the day & A few hours \\
\hline \multirow[t]{3}{*}{$\begin{array}{l}\text { 7. Legal security } \\
\text { index }\end{array}$} & $\begin{array}{l}\text { Legal department in the organizational } \\
\text { structure }\end{array}$ & No & One person & Operates constantly \\
\hline & Number of appeals to court (per year) & More than 2 & 1-2 appeals & No appeal \\
\hline & $\%$ of won cases & Up to $80 \%$ & $81-99 \%$ & $100 \%$ or not \\
\hline
\end{tabular}




\begin{tabular}{|c|c|c|c|c|}
\hline 1 & 2 & 3 & 4 & 5 \\
\hline \multirow[t]{2}{*}{$\begin{array}{l}\text { 7. Legal security } \\
\text { index }\end{array}$} & $\begin{array}{l}\text { Number of raider attacks (for the } \\
\text { whole period of work) }\end{array}$ & Several attacks & $\begin{array}{l}\text { One, there was no } \\
\text { significant loss }\end{array}$ & No attack \\
\hline & $\begin{array}{l}\% \text { of claims that ended for the } \\
\text { institution with resources lost }\end{array}$ & More than $10 \%$ & $1-10 \%$ & $0 \%$ \\
\hline \multirow[t]{5}{*}{$\begin{array}{l}\text { 8. Market (external) } \\
\text { security index }\end{array}$} & An institution in rating charts & Not included in ratings & $\begin{array}{l}\text { Included in the top } 20 \\
\text { institutions }\end{array}$ & $\begin{array}{l}\text { Included in } 10 \text { top } \\
\text { institutions }\end{array}$ \\
\hline & Period of work in the market & Up to 2 years & $2-5$ years & More than 5 years \\
\hline & Number of competitors & $\begin{array}{l}\text { More than } 300 \\
\text { institutions }\end{array}$ & $100-300$ institutions & Up to 100 institutions \\
\hline & Force majeure circumstances & Yes, present now & $\begin{array}{l}\text { Yes, but do not exert } \\
\text { direct influence }\end{array}$ & No \\
\hline & The political situation in the country & Tense & Stable & $\begin{array}{l}\text { Favourable for the } \\
\text { financial market } \\
\text { development }\end{array}$ \\
\hline
\end{tabular}

\section{A methodological approach to assessing the level of economic security of financial institutions}

The maximum score for each intermediate indice is 15 points, and the minimum score is 5 points. In order to obtain a reliable and objective assessment of the economic security level, each indicator for indice should have its own relative weight, given its significance for the status of the functional component of the financial institutions' economic security system. This specific weight, as well as the specific weight of the intermediate indices in the final, integral indice, is determined using the Fishburne formula. For the indicators of the components of the financial institution economic security, xi $(\mathrm{i}=(\overline{1, n}))-$ for this case $\mathrm{n}=5$ for the group of indicators of one indice and $n=40$ for the whole system of indices - within each indicator is evaluated its significance. Then the system of weights is constructed, so that:

$$
\left\{\begin{array}{c}
\sum_{i=1}^{n} a_{i}=1, \\
a_{i} \geq 0, i=\overline{1, n}
\end{array}\right.
$$

where ai is the weight of indicator, and $\mathrm{i}-$ the number of the current indicator, $\mathrm{n}$ - the number of indicators. Indicators are ranked within each intermediate indice for assessing the economic security level in the order of decreasing their significance, that is, $\mathrm{x} 1>\mathrm{x} 2>\mathrm{x} 3>\ldots \ldots .>$ $\mathrm{x}>$...... $>\mathrm{xn}$.

The scientific and methodological basis of using the Fishburne scale is as follows: the scale of the Fishburne is rational fractions whose denominator contains the sum of the arithmetic progression $\mathrm{N}$ of the first members of the natural series in step 1 , and in the numerator, the elements of the natural series from $\mathrm{N}$ to 1 , decreasing continuously by 1 (for example, $3 / 6,2 / 6,1 / 6$ - in total we get 1$)$. That is, the preference or significance of a given Fishburne index will be expressed in a reduction in the weight ratio (index) of a rational fraction of the numerator with a lower level of significance (weaker alternative). The decision to use this method to identify weigh of indicators and indices for assessing the level of economic security of financial institutions for the needs of the study is due to the benefits of the Fishburne's approach, in particular:

- no not need to spend resources on the development of questionnaires, conduct expert surveys and initiate the processing of the data - experts immediately put out specific and fair, in their view, assessments;

- for the use of this method, there are no restrictions that will not allow using the author's methodical approach to assessing the level of economic security of financial institutions even in the case of changing the basic conditions for the functioning of their economic security system;

- the method allows to take into account additional information on the state of indices and indicators, which appears in the process of assessing the level of economic security of professional participants in the financial market, and to make adjustments to the calculations on the basis of additional information;

- there is no need to implement the realization of calculations by a complex mathematical algorithm.

Consequently, we will determine the weighting factors of indicators in the intermediate indices for assessing the level of economic security using the Fishburne scale (formula 2).

$$
a_{i}=\frac{2 \cdot(n-i+1)}{n \cdot(n+1)}
$$

In the proposed methodological approach to assessing the level of economic security of financial institutions, 8 groups of indicators (for the diagnosis of the status of intermediate indices) were formed, 5 in each group. So, for each indicator we have:

$$
\begin{aligned}
& a_{1}=\frac{2 \cdot 5}{5 \cdot 6}=\frac{1}{3}=0,3333 \\
& a_{2}=\frac{2 \cdot 4}{5 \cdot 6}=\frac{4}{15}=0,2667
\end{aligned}
$$




$$
\begin{aligned}
& a_{3}=\frac{2 \cdot 3}{5 \cdot 6}=\frac{1}{5}=0,2 \\
& a_{4}=\frac{2 \cdot 2}{5 \cdot 6}=\frac{2}{15}=0,1333 \\
& a_{5}=\frac{2 \cdot 1}{5 \cdot 6}=\frac{1}{15}=0,0667
\end{aligned}
$$

So we get the weight of each indicator within the evaluation of a specific intermediate indice. Next, it was necessary to determine how indicators within each group are ranked by their values for the level of economic security of the financial institution. To solve the task, five experts were interviewed for each of the 8 groups of indicators. The resulting weighting factor is calculated as the arithmetic mean of the scales proposed by the experts. For example, the indicator of the level of financial independence of the institution in the financial security indicators group was placed by the first and second experts in the third place in importance, and the third expert put it on the fourth place. Therefore, for it, the weight factor will be:

$$
\bar{a}_{3}=\frac{a_{3}+a_{3}+a_{4}}{3}=\frac{0,2+0,2+0,1333}{3}=0,1777
$$

where $\overline{a_{3}}-$ the arithmetic mean of the $\mathrm{i}$-th indicator.

Such calculations were made for each indicator of the level of economic security of the financial institution within each intermediate indice. Thus, the experts - specialists in certain areas of financial institutions activity - established the importance of the author's set of indicators for diagnosing the state of economic security of professional participants in financial services markets.

Table 2 summarizes the results of an expert assessment of the weight factors for indicators of the financial institutions' financial security level.

Consequently, the general formula for calculating the financial security indice of a financial institution is:

$$
\operatorname{In}_{\mathrm{f}}=0,2667 \mathrm{I}_{1}+0,1333 \mathrm{I}_{2}+0,1867 \mathrm{I}_{3}+0,32 \mathrm{I}_{4}+0,0934 \mathrm{I}_{5} \text {, (3) }
$$

where $\mathrm{In}_{\mathrm{f}}-$ financial security indice, $\mathrm{I}_{1}-\mathrm{I}_{5}$ - indicators from Table 2.

Table 3 depicts the results of an expert assessment of weighting factors for indicators of the level of intellectual and personnel security.

The general formula for calculating the intelligence and personnel security indice of a financial institution is:

$\mathrm{In}_{\text {ip }}=0,1467 \mathrm{I}_{1}+0,2933 \mathrm{I}_{2}+0,3067 \mathrm{I}_{3}+0,1733 \mathrm{I}_{4}+0,08 \mathrm{I}_{5}$, (4)

where $\mathrm{In}_{\mathrm{ip}}$ - intelligence and personnel security indice, $I_{1}-I_{5}$ - indicators from Table 3.

Table 4 shows the results of expert evaluation of the values of weight factors for indicators of property (material) security.

Consequently, the formula for calculating the property (material) security indice has the following form:

$\mathrm{In}_{\mathrm{pm}}=0,2800 \mathrm{I}_{1}+0,2 \mathrm{I}_{2}+0,2533 \mathrm{I}_{3}+0,16 \mathrm{I}_{4}+0,1067 \mathrm{I}_{5},(5)$

where $\operatorname{In}_{\mathrm{pm}}$ - property (material) security indice, $\mathrm{I}_{1}-\mathrm{I}_{5}-$ indicators from Table 4.

Table 2

Estimation of the weight factors of indicators of financial security level

\begin{tabular}{|l|c|c|c|c|c|}
\hline \multirow{2}{*}{\multicolumn{1}{c|}{ Expert }} & \multicolumn{5}{|c|}{ Indicators of financial security } \\
\cline { 2 - 6 } & $\begin{array}{c}\text { The result of } \\
\text { economic activity }\end{array}$ & $\begin{array}{c}\text { Financial } \\
\text { independence } \\
\text { (coefficient) }\end{array}$ & Liquidity level & $\begin{array}{c}\text { Compliance with } \\
\text { economic norms } \\
\text { (prudential norms, } \\
\text { regulatory requirements) }\end{array}$ & $\begin{array}{c}\text { Estimation of financial } \\
\text { services consumers } \\
\text { economic security level }\end{array}$ \\
\cline { 2 - 6 } & $\mathrm{I}_{1}$ & $\mathrm{I}_{2}$ & $\mathrm{I}_{3}$ & $\mathrm{I}_{4}$ & $\mathrm{I}_{5}$ \\
\hline First & 0,2667 & 0,2 & 0,1333 & 0,3333 & 0,0667 \\
\hline Second & 0,2667 & 0,1333 & 0,2 & 0,3333 & 0,0667 \\
\hline Third & 0,3333 & 0,1333 & 0,2 & 0,2667 & 0,0667 \\
\hline Fourth & 0,2667 & 0,0667 & 0,1333 & 0,3333 & 0,2 \\
\hline Fifth & 0,2 & 0,1333 & 0,2667 & 0,3333 & 0,0667 \\
\hline Weight factor (average) & 0,2667 & 0,1333 & 0,1867 & 0,3200 & 0,034 \\
\hline
\end{tabular}

Table 3

Estimation of weight factors of indicators of intellectual and personnel security level

\begin{tabular}{|l|c|c|c|c|c|}
\hline \multirow{2}{*}{ Expert } & \multicolumn{4}{|c|}{ Indicators of intellectual and personnel security } \\
\cline { 2 - 6 } & $\begin{array}{c}\text { Higher education } \\
\text { level of the staff }\end{array}$ & $\begin{array}{c}\text { Personnel work } \\
\text { experience in } \\
\text { financial institutions }\end{array}$ & $\begin{array}{c}\text { The period of work } \\
\text { in this institution }\end{array}$ & $\begin{array}{c}\text { \% of people with } \\
\text { economic education }\end{array}$ & $\begin{array}{c}\text { \% of temporarily } \\
\text { employed persons }\end{array}$ \\
\cline { 2 - 6 } & $\mathrm{I}_{1}$ & $\mathrm{I}_{2}$ & $\mathrm{I}_{3}$ & $\mathrm{I}_{4}$ & $\mathrm{I}_{5}$ \\
\hline First & 0,1333 & 0,3333 & 0,2667 & 0,2 & 0,0667 \\
\hline Second & 0,2 & 0,2667 & 0,3333 & 0,1333 & 0,0667 \\
\hline Third & 0,1333 & 0,2667 & 0,3333 & 0,2 & 0,0667 \\
\hline Fourth & 0,0667 & 0,2667 & 0,3333 & 0,2 & 0,1333 \\
\hline Fifth & 0,2 & 0,3333 & 0,2667 & 0,1333 & 0,0667 \\
\hline Weight factor (average) & 0,1467 & 0,2933 & 0,3067 & 0,1733 & 0,0800 \\
\hline
\end{tabular}


Table 5 presents the results of an expert assessment of the values of the weight factors of physical (power) security indicators.

The formula for calculating the indice of physical (power) security has the form:

$$
\mathrm{In}_{\mathrm{pp}}=0,28 \mathrm{I}_{1}+0,16 \mathrm{I}_{2}+0,24 \mathrm{I}_{3}+0,24 \mathrm{I}_{4}+0,08 \mathrm{I}_{5} \text {, }
$$

where $\operatorname{In}_{\mathrm{pp}}$ - physical (power) security indice, $\Pi_{1}-\Pi_{5}-$ indicators from Table 5 .

Table 6 outlines the results of the expert evaluation of weighting factors for indicators of informationanalytical security of financial institutions.

The formula for calculating the indice of information and analytic security has the form:

$\mathrm{In}_{\mathrm{ia}}=0,2533 \mathrm{I}_{1}+0,2267 \mathrm{I}_{2}+0,08 \mathrm{I}_{3}+0,1467 \mathrm{I}_{4}+0,2933 \mathrm{I}_{5},(7)$

where $\mathrm{In}_{\mathrm{ia}}$ - information and analytical security indice, $I_{1}-I_{5}-$ indicators from Table 6 .
Table 7 summarizes the results of the expert evaluation of weighting factors for indicators of the level of technological security of financial institutions.

The formula for calculating the technological security indice is:

$$
\mathrm{In}_{\mathrm{t}}=0,2267 \mathrm{I}_{1}+0,1333 \mathrm{I}_{2}+0,1867 \mathrm{I}_{3}+0,24 \mathrm{I}_{4}+0,2133 \mathrm{I}_{5},(8)
$$

where $I_{n t}-$ technological security indice, $I_{1}-I_{5}-$ indicators from Table 7.

Table 8 presents the results of an expert assessment of weighting factors for indicators of the legal security level of financial institutions.

The formula for calculating the legal indice is as follows:

$$
\mathrm{In}_{\mathrm{l}}=0,24 \mathrm{I}_{1}+0,1067 \mathrm{I}_{2}+0,1733 \mathrm{I}_{3}+0,2267 \mathrm{I}_{4}+0,2533 \mathrm{I}_{5} \text {, (9) }
$$

where $\mathrm{I}_{\mathrm{nl}}-$ legal security indice, $\mathrm{I}_{1}-\mathrm{I}_{5}-$ indicators from Table 8 .

Table 4

Estimation of weight factors of indicators of property (material) security level

\begin{tabular}{|l|c|c|c|c|c|}
\hline \multirow{2}{*}{ Expert } & \multicolumn{4}{|c|}{ Indicators of property (material) security } \\
\cline { 2 - 5 } & $\begin{array}{c}\text { Volume of assets } \\
\text { (in comparison with } \\
\text { average market value) }\end{array}$ & $\begin{array}{c}\text { Depreciation of fixed } \\
\text { assets }\end{array}$ & Branch network & $\begin{array}{c}\text { Ownership of } \\
\text { premises where } \\
\text { offices are located }\end{array}$ & Frequency of audit \\
\cline { 2 - 6 } & $\mathrm{I}_{1}$ & $\mathrm{I}_{2}$ & $\mathrm{I}_{3}$ & $\mathrm{I}_{4}$ & $\mathrm{I}_{5}$ \\
\hline First & 0,3333 & 0,20 & 0,2667 & 0,1333 & 0,0667 \\
\hline Second & 0,2667 & 0,1333 & 0,3333 & 0,2 & 0,0667 \\
\hline Third & 0,2667 & 0,1333 & 0,3333 & 0,0667 & 0,2 \\
\hline Fourth & 0,3333 & 0,2667 & 0,2 & 0,0667 & 0,1333 \\
\hline Weight factor (average) & 0,2 & 0,2667 & 0,1333 & 0,3333 & 0,0667 \\
\hline
\end{tabular}

Table 5

Estimation of weight factors of indicators of physical (power) security level

\begin{tabular}{|l|c|c|c|c|c|}
\hline \multirow{2}{*}{ Expert } & \multicolumn{5}{|c|}{ Indicators of physical (power) security } \\
\cline { 2 - 6 } & Presence of guards & $\begin{array}{c}\text { Use of lattices, } \\
\text { armoured areas }\end{array}$ & $\begin{array}{c}\text { Services of professional } \\
\text { security firms }\end{array}$ & $\begin{array}{c}\text { Access control } \\
\text { systems for resources }\end{array}$ & $\begin{array}{c}\text { Cases of signalling } \\
\text { during the last year }\end{array}$ \\
\cline { 2 - 6 } & $\mathrm{I}_{1}$ & $\mathrm{I}_{2}$ & $\mathrm{I}_{3}$ & $\mathrm{I}_{4}$ & $\mathrm{I}_{5}$ \\
\hline First & 0,3333 & 0,1333 & 0,2667 & 0,2 & 0,0667 \\
\hline Second & 0,3333 & 0,2667 & 0,2 & 0,1333 & 0,0667 \\
\hline Third & 0,3333 & 0,2 & 0,1333 & 0,2667 & 0,0667 \\
\hline Fourth & 0,2 & 0,1333 & 0,2667 & 0,3333 & 0,0667 \\
\hline Fifth & 0,2 & 0,0667 & 0,3333 & 0,2667 & 0,1333 \\
\hline Weight factor (average) & 0,2800 & 0,1600 & 0,2400 & & 0,0800 \\
\hline
\end{tabular}

Table 6

Estimation of weight factors of indicators of information and analytical security level

\begin{tabular}{|l|c|c|c|c|c|}
\hline \multirow{2}{*}{ Expert } & \multicolumn{5}{|c|}{ Indicators of information and analytical security } \\
\cline { 2 - 6 } & $\begin{array}{c}\text { Analytical department } \\
\text { in the organizational } \\
\text { structure }\end{array}$ & $\begin{array}{c}\text { Cases of information } \\
\text { loss during the last year }\end{array}$ & $\begin{array}{c}\text { Access to the Internet } \\
\text { (for personnel) }\end{array}$ & $\begin{array}{c}\text { Transparency } \\
\text { level of activity }\end{array}$ & $\begin{array}{c}\text { Sufficient } \\
\text { information to make } \\
\text { managerial decisions }\end{array}$ \\
\cline { 2 - 6 } & $\mathrm{I}_{1}$ & $\mathrm{I}_{2}$ & $\mathrm{I}_{3}$ & $\mathrm{I}_{4}$ & $\mathrm{I}_{5}$ \\
\hline First & 0,3333 & 0,1333 & 0,0667 & 0,2 & 0,2667 \\
\hline Second & 0,1333 & 0,2667 & 0,0667 & 0,2 & 0,3333 \\
\hline Third & 0,2 & 0,3333 & 0,0667 & 0,1333 & 0,2667 \\
\hline Fourth & 0,2667 & 0,2 & 0,1333 & 0,0667 & 0,3333 \\
\hline Fifth & 0,3333 & 0,2 & 0,0667 & 0,1333 & 0,2667 \\
\hline Weight factor (average) & 0,2533 & 0,2267 & 0,0800 & 0,1467 & 0,2933 \\
\hline
\end{tabular}


Vol. 5, No. 2, 2019

Table 7

Estimation of weight factors of indicators of technological security level

\begin{tabular}{|l|c|c|c|c|c|}
\hline \multirow{2}{*}{ Expert } & \multicolumn{5}{|c|}{ Indicators of technological security } \\
\cline { 2 - 6 } & $\begin{array}{c}\text { \% use of licensed } \\
\text { software }\end{array}$ & $\begin{array}{c}\text { Frequency of } \\
\text { software update }\end{array}$ & $\begin{array}{c}\text { Depreciation of } \\
\text { equipment }\end{array}$ & $\begin{array}{c}\text { IT department in the } \\
\text { organizational structure }\end{array}$ & $\begin{array}{c}\text { Speed recovery of } \\
\text { equipment after failures }\end{array}$ \\
\cline { 2 - 6 } & $\mathrm{I}_{1}$ & $\mathrm{I}_{2}$ & $\mathrm{I}_{3}$ & $\mathrm{I}_{4}$ & $\mathrm{I}_{5}$ \\
\hline First & 0,2667 & 0,0667 & 0,2 & 0,3333 & 0,1333 \\
\hline Second & 0,2667 & 0,1333 & 0,0667 & 0,3333 & 0,2 \\
\hline Third & 0,2 & 0,0667 & 0,3333 & 0,1333 & 0,2667 \\
\hline Fourth & 0,1333 & 0,0667 & 0,2 & 0,3333 & 0,2667 \\
\hline Fifth & 0,2667 & 0,3333 & 0,1333 & 0,0667 & 0,2 \\
\hline Weight factor (average) & 0,2267 & 0,1333 & 0,1867 & 0,2400 & 0,2133 \\
\hline
\end{tabular}

Table 8

Estimation of the weight factors of indicators of legal security level

\begin{tabular}{|l|c|c|c|c|c|}
\hline \multirow{2}{*}{ Expert } & \multicolumn{5}{|c|}{ Indicators of legal security } \\
\cline { 2 - 6 } & $\begin{array}{c}\text { Legal department in the } \\
\text { organizational structure }\end{array}$ & $\begin{array}{c}\text { Number of } \\
\text { appeals to court } \\
\text { (per year) }\end{array}$ & \% of won cases & $\begin{array}{c}\text { Number of raider attacks } \\
\text { (for the whole period of } \\
\text { work) }\end{array}$ & $\begin{array}{c}\text { \% of claims that ended } \\
\text { for the institution } \\
\text { with resources lost }\end{array}$ \\
\cline { 2 - 6 } & $\mathrm{I}_{1}$ & $\mathrm{I}_{2}$ & $\mathrm{I}_{3}$ & $\mathrm{I}_{4}$ & $\mathrm{I}_{5}$ \\
\hline First & 0,2667 & 0,0667 & 0,1333 & 0,3333 & 0,2 \\
\hline Second & 0,3333 & 0,0667 & 0,1333 & 0,2 & 0,2667 \\
\hline Third & 0,2667 & 0,0667 & 0,1333 & 0,2 & 0,3333 \\
\hline Fourth & 0,2667 & 0,1333 & 0,3333 & 0,0667 & 0,2 \\
\hline Fifth & 0,0667 & 0,2 & 0,1333 & 0,3333 & 0,2667 \\
\hline Weight factor (average) & 0,2400 & 0,1067 & 0,1733 & 0,2267 & 0,2533 \\
\hline
\end{tabular}

Table 9

Estimation of weight factors of indicators of market (external) security level

\begin{tabular}{|l|c|c|c|c|c|}
\hline \multirow{2}{*}{ Expert } & \multicolumn{5}{|c|}{ Indicators of market (external) security } \\
\cline { 2 - 6 } & $\begin{array}{c}\text { Institution in rating } \\
\text { charts }\end{array}$ & $\begin{array}{c}\text { Period of work in the } \\
\text { market }\end{array}$ & $\begin{array}{c}\text { Number } \\
\text { of competitors }\end{array}$ & $\begin{array}{c}\text { Force majeure } \\
\text { circumstances }\end{array}$ & $\begin{array}{c}\text { Political situation } \\
\text { in the country }\end{array}$ \\
\cline { 2 - 6 } & $\mathrm{I}_{1}$ & $\mathrm{I}_{2}$ & $\mathrm{I}_{3}$ & $\mathrm{I}_{4}$ & $\mathrm{I}_{5}$ \\
\hline First & 0,3333 & 0,2667 & 0,1333 & 0,2 & 0,0667 \\
\hline Second & 0,2667 & 0,3333 & 0,2 & 0,0667 & 0,1333 \\
\hline Third & 0,2 & 0,3333 & 0,2667 & 0,0667 & 0,1333 \\
\hline Fourth & 0,2667 & 0,2 & 0,0667 & 0,3333 & 0,1333 \\
\hline Fifth & 0,2667 & 0,3333 & 0,1333 & 0,2 & 0,0667 \\
\hline Weight factor (average) & 0,2667 & 0,2933 & 0,1600 & 0,1733 & 0,1067 \\
\hline
\end{tabular}

Table 9 shows the results of an expert assessment of the weight factors of indicators of the level of market (external) security of financial institutions.

The general formula for calculating the indice of the market (external) security is:

$\mathrm{In}_{\mathrm{me}}=0,2667 \mathrm{I}_{1}+0,2933 \mathrm{I}_{2}+0,16 \mathrm{I}_{3}+0,1733 \mathrm{I}_{4}+0,1067 \mathrm{I}_{5},(10)$

where $\mathrm{In}_{\mathrm{me}}-$ market (external) security indice, $\mathrm{I}_{1}-\mathrm{I}_{5}-$ indicators from Table 9.

To determine the weights of the intermediate indices of economic security in the final (integral) indice, we apply the Fishburne formula again:

$$
\begin{aligned}
& a_{1}=\frac{2 \cdot 8}{8 \cdot 9}=\frac{2}{9}=0,2222 \\
& a_{2}=\frac{2 \cdot 7}{8 \cdot 9}=\frac{7}{36}=0,1944
\end{aligned}
$$

$$
\begin{aligned}
& a_{3}=\frac{2 \cdot 6}{8 \cdot 9}=\frac{1}{6}=0,1667 \\
& a_{4}=\frac{2 \cdot 5}{8 \cdot 9}=\frac{5}{36}=0,1389 \\
& a_{5}=\frac{2 \cdot 4}{8 \cdot 9}=\frac{1}{9}=0,1111 \\
& a_{6}=\frac{2 \cdot 3}{8 \cdot 9}=\frac{1}{12}=0,0833 \\
& a_{7}=\frac{2 \cdot 2}{8 \cdot 9}=\frac{1}{18}=0,0556 \\
& a_{8}=\frac{2 \cdot 1}{8 \cdot 9}=\frac{1}{36}=0,0278
\end{aligned}
$$

Table 10 presents the results of an expert evaluation of the weighting factors of all intermediate indices 
Table 10

Expert assessment of the weight factors of intermediate indices depending on the type of financial institution in the integral indice of economic security level

\begin{tabular}{|c|c|c|c|c|c|c|c|c|}
\hline \multirow[b]{2}{*}{ Type of financial institution } & \multicolumn{8}{|c|}{ Weight of indices in economic security level } \\
\hline & 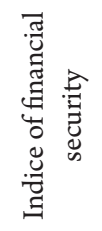 & 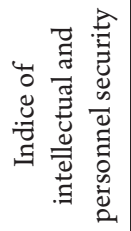 & 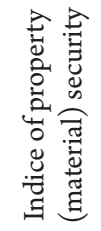 & 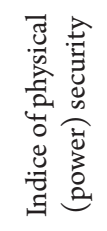 & 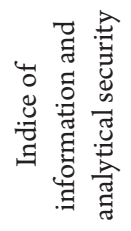 & 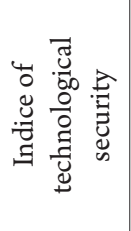 & 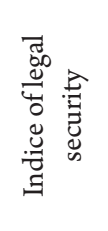 & 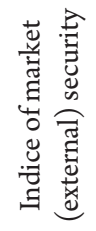 \\
\hline Banks & 0,2111 & 0,1833 & 0,1611 & 0,1000 & 0,1389 & 0,0556 & 0,1056 & 0,0445 \\
\hline Insurance companies & 0,2111 & 0,1445 & 0,2055 & 0,0667 & 0,1167 & 0,0334 & 0,1445 & 0,0778 \\
\hline $\begin{array}{l}\text { Credit unions and other institutions of the } \\
\text { sector of credit co-operation }\end{array}$ & 0,15 & 0,0556 & 0,2 & 0,1056 & 0,1333 & 0,0833 & 0,1389 & 0,1333 \\
\hline $\begin{array}{l}\text { Investment companies (asset management } \\
\text { companies, non-state pension funds, etc.) }\end{array}$ & 0,2166 & 0,1556 & 0,0722 & 0,0889 & 0,2 & 0,15 & 0,0278 & 0,0889 \\
\hline Financial companies & 0,2111 & 0,0778 & 0,1555 & 0,05 & 0,1278 & 0,1 & 0,1333 & 0,1444 \\
\hline
\end{tabular}

of financial institutions economic security level. The evaluation was carried out according to an algorithm analogous to the estimation of the weighting factors of indicators of each intermediate indice, therefore in Table 10, only the final result of an expert evaluation is presented. Note that for different types of financial institutions, different weights were determined for adjusting the values of the same indices. This is explained by the specifics of the functioning of the different types of financial institutions and the peculiarities of the construction of internal mechanisms for the protection of their resources within the framework of ensuring economic security.

The data obtained from experts and processed by means of mathematical calculations provide an opportunity to propose formulas for assessing the level of economic security for various types of financial institutions:

$$
\begin{aligned}
& I_{s(\text { bank })}=0,2111 \operatorname{In}_{\mathrm{f}}+0,1833 \operatorname{In}_{\text {ip }}+0,1611 \mathrm{In}_{\mathrm{pm}}+0,1 \mathrm{In}_{\mathrm{pp}}+0,1389 \operatorname{In}_{\mathrm{ia}}+0,0556 \operatorname{In}_{\mathrm{t}}+0,1056 \operatorname{In}_{1}++0,0445 \operatorname{In}_{\mathrm{me}} \text {; } \\
& \mathrm{I}_{\mathrm{s} \text { (insurance company) }}=0,2111 \mathrm{In}_{\mathrm{f}}+0,1445 \operatorname{In}_{\mathrm{ip}}+0,2055 \operatorname{In}_{\mathrm{pm}}+0,0667 \operatorname{In}_{\mathrm{pp}}+0,1167 \operatorname{In}_{\mathrm{ia}}+0,0334 \operatorname{In}_{\mathrm{t}}++0,1445 \operatorname{In}_{1}+0,0778 \operatorname{In}_{\mathrm{me}} \text {; } \\
& \mathrm{I}_{\mathrm{s}(\text { credit union) }}=0,15 \mathrm{In}_{\mathrm{f}}+0,556 \operatorname{In}_{\mathrm{ip}}+0,2 \mathrm{In}_{\mathrm{pm}}+0,1056 \mathrm{In}_{\mathrm{pp}}+0,1333 \operatorname{In}_{\mathrm{ia}}+0,0833 \operatorname{In}_{\mathrm{t}}+0,1389 \operatorname{In}_{1}++0,1333 \operatorname{In}_{\mathrm{me}} \text {; } \\
& \mathrm{I}_{\mathrm{s} \text { (investment company) }}=0,2166 \operatorname{In}_{\mathrm{f}}+0,1556 \operatorname{In}_{\mathrm{ip}}+0,0722 \operatorname{In}_{\mathrm{pm}}+0,0889 \operatorname{In}_{\mathrm{pp}}+0,2 \operatorname{In}_{\mathrm{ia}}+0,15 \operatorname{In}_{\mathrm{t}}++0,0278 \operatorname{In}_{1}+0,0889 \operatorname{In}_{\mathrm{me}} \text {; } \\
& I_{s \text { (financial company) }}=0,2111 \operatorname{In}_{\mathrm{f}}+0,0778 \operatorname{In}_{\mathrm{ip}}+0,1555 \operatorname{In}_{\mathrm{pm}}+0,05 \operatorname{In}_{\mathrm{pp}}+0,1278 \operatorname{In}_{\mathrm{ia}}+0,1 \mathrm{In}_{\mathrm{t}}++0,1333 \operatorname{In}_{1}+0,1444 \operatorname{In}_{\mathrm{me}} \text {; }
\end{aligned}
$$

Since, according to the proposed methodological approach, the maximum score of each intermediate indice is 15 points (if all five its indicators are estimated at 3 points), and the minimum is 5 points (if all five its indicators are estimated at 1 point), then after adjusting the estimates of indicators and indices for the above weighting factors, it is necessary to determine the quantitative limits of possible qualitative characteristics of the levels of economic security of financial institutions using equal intervals of probable values: critical level of economic security $-5 \leq \mathrm{I}_{s}<7$; minimum level of economic security $-7 \leq I_{s}<9$; satisfactory level of economic security $-9 \leq \mathrm{I}_{\mathrm{s}}<11$; high level of economic security $-11 \leq \mathrm{I}_{\mathrm{s}}<13$; maximum level of economic security $-13 \leq \mathrm{I}_{s} \leq 15$.

\section{Possibilities of using the results of assessing economic security level in management and regulatory activity}

With actual and reliable information on the level of economic security of a financial institution, its owners and top management will be able to make right management decisions regarding the strategic orientations of the economic development of the institution and tactical measures of its economic activity. Regulators of financial services markets based on the data of economic security state of their professional participants will be able to timely identify financial intermediaries who are in danger of bankruptcy and liquidation, and whose subsequent activities, without proper control and support, can have fatal consequences for the welfare of their clients. Possibilities for using the results of assessing the level of economic security in management and regulatory activities are summarized in Table 11.

\section{Conclusions}

The possibility of using the results of the assessment of the level of economic security of financial institutions by the top-management of professional participants in the financial market has been established. At a critical level of economic security, the heads of institutions are 
Vol. 5, No. 2, 2019

Table 11

Possibilities of using the results of assessing economic security level in management and regulatory activity

\begin{tabular}{|c|c|c|}
\hline $\begin{array}{l}\text { The level } \\
\text { of security }\end{array}$ & Options for managerial decisions for top management & $\begin{array}{l}\text { Options for regulators of financial services markets } \\
\text { in order to ensure the financial security of the state }\end{array}$ \\
\hline Critical & $\begin{array}{l}\text { Optimization of the organizational structure with the } \\
\text { allocation of the economic security subdivision; external } \\
\text { specialists involvement for the formation of mechanisms for } \\
\text { protecting the institution from all kinds of threats; attraction } \\
\text { of funding sources for security measures; start of preventive } \\
\text { risk management; development of documentation support } \\
\text { for the economic security system functioning }\end{array}$ & $\begin{array}{l}\text { Conduct a monitoring of the institution's activities in } \\
\text { retrospect; investigation of the circumstances that caused } \\
\text { the economic danger; consideration of the possibility of a } \\
\text { financial intermediary leaving the market and taking measures } \\
\text { to secure the financial interests of its clients; introduction of a } \\
\text { temporary administration; for systemic financial institution - } \\
\text { consideration of the possibility of their nationalization }\end{array}$ \\
\hline Minimum & $\begin{array}{l}\text { Development of the concept and strategy of ensuring } \\
\text { economic security; organization of training of personnel } \\
\text { involved in the problematic subsystems of economic security } \\
\text { process; increasing the frequency of inspections of the } \\
\text { state of security; increasing the budget of financing security } \\
\text { measures; establishing a clear list of tasks for those involved in } \\
\text { the development of threats response }\end{array}$ & $\begin{array}{l}\text { Strengthening oversight of the institution's activities; taking } \\
\text { control of its operations and processes for the implementation } \\
\text { of financial products and services; advising on improving } \\
\text { security; sending experts, consultants and supervisors to } \\
\text { restore economic security; carrying out a re-examination and } \\
\text { assessment of the level of economic security in six months }\end{array}$ \\
\hline Satisfactory & $\begin{array}{l}\text { Aiming temporarily free financial resources for security } \\
\text { measures; increase staffing in security departments; } \\
\text { invitation of consultants from specialized firms to optimize } \\
\text { the architecture of the economic security system; the } \\
\text { introduction of security-oriented management }\end{array}$ & $\begin{array}{l}\text { Providing recommendations and consultations on raising the } \\
\text { level of economic security; control over the activity of the } \\
\text { institution in the usual mode; consideration of the possibility } \\
\text { of state support to the institution in the future; conduct a } \\
\text { re-examination and assessment of the level of security }\end{array}$ \\
\hline High & $\begin{array}{l}\text { Increasing the level of transparency of the institution; } \\
\text { formation of the image of a financial intermediary capable of } \\
\text { protecting the assets of clients; introduction of the practice } \\
\text { of customer service taking into account the level of their } \\
\text { economic security; re-assessing the level of economic security } \\
\text { in six months }\end{array}$ & $\begin{array}{l}\text { Involvement the top-management of the institution to form } \\
\text { groups of experts for consultations of raising the level of } \\
\text { economic security for other market participants; minimal } \\
\text { control and supervision for the institution; allocation of high } \\
\text { ranking positions in national ratings }\end{array}$ \\
\hline Maximum & $\begin{array}{l}\text { Expansion and diversification of financial activities in order } \\
\text { to increase profitability; search for competitive advantages; } \\
\text { taking measures to maintain the achieved level of economic } \\
\text { security }\end{array}$ & $\begin{array}{l}\text { Work with the management of financial institution on the } \\
\text { advisory and consultative basis; provision of state guarantees } \\
\text { in case of necessity of expansion of activity; use of financial } \\
\text { intermediation services of an institution for work with state } \\
\text { financial resources }\end{array}$ \\
\hline
\end{tabular}

invited to optimize the organizational structure with the allocation of the economic security unit, to seek the help of specialists, to develop preventive measures against the internal and external threats. At a minimum level of economic security, it is expedient to develop or update the conceptual framework for the functioning of the economic security system and pay attention to its development strategy. At a satisfactory level of economic security, it is recommended that a human resources policy be launched to establish securityoriented management of the financial institution. At a high level of economic security, efforts should be made to publicize this fact by extending the transparency of the financial institution's activities. This will promote a positive image of the company in the financial market and attract new customers. At the maximum level of economic security, managerial decisions of top management should be aimed at achieving a balance between its maintenance and the allocation of resources for the development of the institution and expansion of its activities.

The expediency of using by the state financial regulators the information obtained in the process of assessing the level of economic security of financial institutions for the purpose of realization of the goal of ensuring the financial security of the state through the mechanism of monitoring and control of the results of activities of financial intermediaries has been substantiated.

\section{References:}

(n.d.) American History: Roosevelt Aims for Economic Security With «Second New Deal». Retrieved from: https: / / learningenglish.voanews.com/a/american-history-president-roosevelt-aims-for-economic-security-withsecond-new-deal-119369809/116068.html

Stiglitz, J. (2002). Financial Market Stability and Monetary Policy. Pacific Economic Review, 7(1), 13-30.

Creamer, R. (2011). The Dominance of the Financial Sector Has Become a Mortal Danger to Our Economic Security. Retrieved from: https://www.huffingtonpost.com/robert-creamer/the-dominance-of-the-fina b 317310.html (accessed 10 August 2018). 
Athanasoulis, S., Shiller, R., van Wincoop E. (1999). Macro Markets and Financial Security. FRBNY Economic policy review, April, pp. 21-39.

Osberg, L., Sharpe, A. (2008). Economic Security in Nova Scotia. CSLS Research Reports 2008-05, Centre for the Study of Living Standards.

Ioan-Franc, V., Diamescu, M. A. (2010). Some Opinions on the Relation between Security Economy and Economic Security. Retrieved from: http://www.revecon.ro/articles/2010-2/2010-2-7.pdf (accessed 20 August 2018).

Schimmel, K., Liu, S., Nicholls, J., Nechval, N. A., Yi-Lin Forrest, J. (2017). Economic Security under Disturbances of Foreign Capital. Advances in Systems Science and Applications, 17 (2), 14-28.

Kopp, E., Kaffenberger, L., Wilson, C. (2017). Cyber Risk, Market Failures and Financial Stability. IMF Working Paper, WP/17/185.

Elliott, D. J. (2017). Financial Institutions in an Age of Populism. Oliver Wyman, March, 18 p.

Matanda, E. (2015). Threats and Opportunities Facing Banking Institutions in Emerging Economies in their Desire to Adopt and Implement the Basel II Capital Accord: A Case Study of the Zimbabwean Economy in the Dollarization Era. International Review of Research in Emerging Markets and the Global Economy (IRREM) An Online International Research Journal, 1/3, 441-454.

Piotrowska, M. (2017). The Impact of Consumer Behavior on Financial Security of Households in Poland. Contaduría y Administración, 62/2, 461-504.

Kośny, M., Piotrowska, M. Economic Security of Households: Assessment Based on Scenario Analysis. Retrieved from: http://www.ecineq.org/ecineq_bari13/FILESxBari13/CR2/p183.pdf (accessed 27 June 2018).

Perciun, R., Stratan, A., Timush, A. (2014). The Methodology of Financial Stability Assessment of Republic of Moldova through macroeconomic indicators. Procedia Economics and Finance, 15, 383-392.

Hacker, J. S., Huber, G., Nichols, A., Rehm, P., Schlesinger, M., Valletta, R. G., Craig, S. (2012). The Economic Security Index: A New Measure for Research and Policy Analysis. Federal Reserve Bank of San Francisco. Working paper series. Working Paper, 21, 56.

Dyakonova, I., Nikitina, A., Sukhonos, V., Zhuravka, F. (2018). Methodological Bases of Estimating the Efficiency of Economic Security Management of the Enterprises in the Global Environment. Investment Management and Financial Innovations, 15(2), 145-153.

Baranovskyy, O. I. (2006). Bankivska bezpeka: problema vymiru [Banking security: the measurement problem]. Ekonomika i prohnozuvannya, 1, 7-25.

Momot, T. V., Ovchelupova, O. M., Solovyova, K. S. (2015). Otsinka rivnya finansovo-ekonomichnoyi bezpeky bankivskykh ustanov v umovakh kryzy [Assessment of the level of financial and economic security of banking institutions in a crisis]. Komunalne hospodarstvo mist, 125, 32-36.

Shtefan, L. B. (2017). Problemy formuvannya universalnoyi systemy otsinyuvannya finansovoyi bezpeky banku ta bankivskoyi systemy [Problems of forming a universal system for assessing the financial safety of the bank and the banking system]. Ekonomika i suspilstvo, 9, 1100-1106.

Kozachenko, H. V. (2016). Estymetolohichnyy aspekt v ekonomichniy bezpekolohiyi [The estimetological aspect in economic securityology]. Problemy ekonomiky, 1, 167-173. 